\title{
Precipitation Influences Pre- and Post-Emergence Herbicide Efficacy in Corn
}

\author{
Christie L. Stewart ${ }^{1}$, Nader Soltani ${ }^{*}$, Robert E. Nurse ${ }^{2}$, Allan S. Hamill ${ }^{2}$, Peter H. Sikkema ${ }^{1}$ \\ ${ }^{1}$ University of Guelph Ridgetown Campus, Ridgetown, Canada; ${ }^{2}$ Agriculture and Agri-Food Canada, Harrow, Canada. \\ Email: "nsoltani@ridgetownc.uoguelph.ca
}

Received June $6^{\text {th }}, 2012$; revised July $4^{\text {th }}, 2012$; accepted July $12^{\text {th }}, 2012$

\begin{abstract}
Selecting a preemergence (PRE) and postemergence (POST) herbicide program that has the greatest efficacy can be difficult for corn producers and is highly dependent on weed spectrum. Weather conditions before and after herbicide application can further complicate decisions because they influence herbicide efficacy. Eleven field trials were conducted at three locations in Southwestern Ontario from 2003 to 2006, to determine the most effective PRE and POST corn herbicides for weed control. The most abundant weed species across all locations were redroot pigweed (Amaranthus retroflexus L.), common ragweed (Ambrosia artemisiifolia L.), common lambsquarters (Chenopodium album L.), and green foxtail (Setaria viridis (L.) Beauv.). Nine PRE herbicide treatments and eleven POST (applied at the 3 - 4 leaf stage of corn) herbicide treatments were tested. Results from this study suggest that the timing and amount of precipitation influence herbicide efficacy. For example, precipitation levels 0 - $17 \mathrm{~mm}$ within seven days after herbicide application (PRE or POST) provided unacceptable weed control in treatments that included atrazine, dimethenamid-p, isoxaflutole/atrazine or $S$-metolachlor/benoxacor. Cumulative precipitation during the 14 days after PRE application that exceeded the monthly average (by at least 64\%) reduced Setaria viridis control with pendimethalin. This study demonstrates that a better understanding of how environmental conditions, especially precipitation affect herbicide efficacy, need to be considered by growers when selecting a corn herbicide program to reduce the possibility of weed control failure.
\end{abstract}

Keywords: Preemergence Herbicides; Postemergence Herbicides; Tank-Mixture; Precipitation

\section{Introduction}

Weather conditions, specifically precipitation amount and timing, can significantly impact the efficacy of individual preemergence (PRE) and postemergence (POST) herbicides [1-5]. When tank-mixed, the conditions underwhich each herbicide has the greatest efficacy can differ [1]. However, this also means that tank-mixtures have the potential to provide more consistent weed control over a broader range of climatic conditions [6]. Tankmixing herbicides is also an effective way to combine several herbicide modes of action and control a broad spectrum of weeds, while also being cost effective by reducing the requirement for multiple applications [6-9].

Some growers attempt to implement a PRE only program for weed control [10], which can be problematic if the PRE herbicide fails to control all weeds. However, the grower always has the opportunity to apply a POST herbicide should a failure occur $[11,12]$. The benefit of including a POST component is that it allows the grower to make herbicide choices based on the weed spectrum in

${ }^{*}$ Corresponding author. each individual field [13]. However, timing POST herbicide application with weed size is critical [8]; if weeds become too large, control can be reduced $[11,14]$. Weather conditions at the optimum weed size prevents accurate timing of POST application allowing weeds the opportunity to become too large for effective control $[11,15,16]$.

For most PRE herbicides precipitation is required within 7 - 14 days after application to dissolve the herbicide in soil water solution so that it can be taken up by the emerging weeds after germination [10,17-20]. Inadequate or delayed precipitation can reduce herbicide effectiveness and decrease weed control [1,4,11,21-23]. Depending on soil type, high amounts of precipitation (i.e. greater than $25 \mathrm{~mm}$ ), especially immediately after application, can cause herbicides to leach through the soil profile and consequently reduce efficacy $[6,24,25]$. Most POST herbicides require that there is no precipitation for several hours after application to ensure that movement across the leaf membrane can occur.

It is widely known that PRE herbicides such as $S$-metolachlor/benoxacor/atrazine, isoxaflutole + atrazine, and 
dimethenamid-p + atrazine require precipitation within 7-10 days after application for proper movement into the active zone of weed seed germination [26-29]. However, when several modes of action are being tank-mixed, the differential sensitivity of each herbicide to precipitation can become complicated. For example, $S$-metolachlor/ benoxacor/atrazine, an acetanilide/s-triazine mixture that controls a broad-spectrum of annual grasses and broadleaved weeds $[6,12,17]$ requires precipitation within 7 10 days for proper activation [1]. However, precipitation greater than $45 \mathrm{~mm}$, over 2 days, beginning within 12 hours of application may result in leaching of the atrazine component away from the active zone of weed seed germination [3]. It is possible that if S-metolachlor/benoxacor/atrazine is tank-mixed with an additional mode of action such as mesotrione that there would be no decrease in broadleaved weed control because mesotrione may respond differently to precipitation after application. Pendimethalin is an example of an herbicide that is more persistent in the soil under dry conditions and can affect rotational crops, but is easily leached when soil conditions are wet $[27,30,31]$. Furthermore, pendimethalin's weed spectrum is reduced, especially the control of annual grasses, when soil conditions are dry up to 3 weeks after application [2].

Glyphosate is a non-selective, broad-spectrum herbicide used to control many annual grasses and broadleaved weeds post emergently [32]. This herbicide lacks residual control which allows weeds to emerge after application and escape control [33-35]; however, sequential in-crop applications of glyphosate are effective at controlling late-emerging weeds [36,37]. Glyphosate efficacy can be reduced by precipitation occurring $15 \mathrm{~min}$ to $6 \mathrm{hr}$ after application depending on formulation [24,25, 27]. Thus application may have to be delayed and weed size at the time of application may no longer be optimal.

Field-specific data from diverse environments that describe the performance of herbicide mixtures registered for corn are needed. These data will help to identify weed management strategies that provide season-long weed control without reducing crop yields under variable precipitation. Therefore, the specific objectives of this research were to 1) determine the most effective PRE and POST herbicide mixtures for corn when precipitation varies within 14 days of application; 2) determine if a glyphosate only or conventional management strategy is better in unfavourable environmental conditions.

\section{Materials and Methods}

Eleven field trials were conducted from 2003 to 2006 at the Huron Research Station, Exeter, Ontario, and the University of Guelph, Ridgetown Campus, Ridgetown, Ontario and from 2004 to 2006 at the Greenhouse and
Processing Crops Research Centre, Agriculture and AgriFood Canada, Harrow, Ontario. Soil characteristics are presented in Table 1 and precipitation in Table 2. Procedures at all sites were the same unless otherwise noted. The soil was moldboard plowed in the fall and the seedbed was prepared with two passes with an s-tine cultivator with rolling basket harrows the following spring of each year. A total of twenty treatments were tested in two separate trials (Trial $1=$ PRE and Trial $2=$ POST) at each location. The first trial consisted of nine PRE treatments: a non-treated weedy control, $S$-metolachlor/benoxacor/atrazine, dimethenamid-p + atrazine, isoxaflutole + atrazine, S-metolachlor/beno- xacor/atrazine + dicamba, dimethenamid-p + dicamba/atrazine, S-metolachlor/benoxacor/atrazine + mesotrione, pendimethalin + dicamba/atrazine, pendimethalin + atrazine and rimsulfuron + $S$-metolachlor/benoxacor + dicamba. Rates for PRE herbicide are listed in Table 3. The second trial consisted of eleven POST treatments that were applied at the $3-4$ leaf stage of the corn unless otherwise stated: a nontreated weedy control, glyphosate (3 - 4 leaf stage), glyphosate (3 - 4 leaf stage) followed by glyphosate (7 - 8 leaf stage), rimsulfuron $+S$-metolachlor/benoxacor + dicamba + a non-ionic surfactant, nicosulfuron/rimsulfuron + dicamba/diflufenzopyr + a non-ionic surfactant + urea ammonium nitrate (UAN), nicosulfuron/rimsulfuron + mesotrione + atrazine + a non-ionic surfactant, nicosulfuron + dicamba/diflufenzopyr + a non-ionic surfactant + UAN, nicosulfuron + prosulfuron + dicamba + a non-ionic surfactant, nicosulfuron + mesotrione + atrazine + a non-ionic surfactant, nicosulfuron + pendimethalin + dicamba + a non-ionic surfactant, nicosulfuron + primisulfuron/dicamba + a non-ionic surfactant, and foramsulfuron + dicamba/diflufenzopyr + UAN + a MSO. Rates for POST herbicides are listed in Table 4.

Glyphosate-resistant corn was seeded in rows spaced $76 \mathrm{~cm}$ apart at densities of at least 74,000 seeds ha ${ }^{-1}$ at each location. Plots were arranged in a randomized complete block design with four replications and plots were 2 $\mathrm{m}$ wide $\times 8$ to $11 \mathrm{~m}$ long.

At Exeter, herbicides were applied using a $\mathrm{CO}_{2}$-pressurized sprayer calibrated to deliver $200 \mathrm{~L} \cdot \mathrm{ha}^{-1}$ aqueous solution at $241 \mathrm{kPa}$ using 8002 VS nozzles (Teejet Spraying Systems Co., P.O. Box 7900, Wheaton, IL 60,188 ) spaced $50 \mathrm{~cm}$ apart. At Ridgetown, herbicides were applied using a $\mathrm{CO}_{2}$-pressurized sprayer calibrated to deliver $200 \mathrm{~L} \cdot \mathrm{ha}^{-1}$ aqueous solution at $207 \mathrm{kPa}$ using 8002 Extended Range $(2003,2004)$ and Ultra Lo-Drift $120-02(2005,2006)$ nozzles spaced $50 \mathrm{~cm}$ apart. At Harrow, herbicides were applied using a $\mathrm{CO}_{2}$-pressurized sprayer calibrated to deliver $247 \mathrm{~L} \cdot \mathrm{ha}^{-1}$ aqueous solution at $210 \mathrm{kPa}$ using flat fan 110-03 XR nozzles spaced $50 \mathrm{~cm}$ apart.

Percent weed control and crop yield were measured at 
Table 1. Soil characteristics for experimental sites at Exeter and Ridgetown, ON in 2003 to 2006 and Harrow, ON in 2004 to 2006.

\begin{tabular}{|c|c|c|c|c|c|c|c|c|}
\hline Location & Year & Application timing ${ }^{a}$ & Soil type & $\mathrm{pH}$ & Organic matter & Sand & Silt & Clay \\
\hline & & & & & \multicolumn{4}{|c|}{$\%$} \\
\hline \multirow[t]{8}{*}{ Exeter } & 2003 & PRE & Brookston clay loam & 7.4 & 3.9 & 39 & 37 & 24 \\
\hline & 2003 & POST & Brookston clay loam & 7.9 & 4.3 & 38 & 41 & 21 \\
\hline & 2004 & PRE & Brookston clay loam & 8.0 & 4.2 & 28 & 38 & 34 \\
\hline & 2004 & POST & Brookston clay loam & 7.9 & 4.7 & 39 & 33 & 28 \\
\hline & 2005 & PRE & Brookston clay loam & 7.6 & 5.3 & 39 & 37 & 24 \\
\hline & 2005 & POST & Brookston clay loam & 7.6 & 5.3 & 39 & 37 & 24 \\
\hline & 2006 & PRE & Brookston clay loam & 7.9 & 3.4 & 33 & 35 & 32 \\
\hline & 2006 & POST & Brookston clay loam & 7.9 & 3.4 & 33 & 35 & 32 \\
\hline \multirow[t]{8}{*}{ Ridgetown } & 2003 & PRE & Loam & 6.4 & 5.2 & 45 & 29 & 26 \\
\hline & 2003 & POST & Fine sandy loam & 7.2 & 4.1 & 57 & 25 & 18 \\
\hline & 2004 & PRE & Loam & 7.4 & 5.0 & 43 & 33 & 24 \\
\hline & 2004 & POST & Loam & 7.0 & 6.4 & 43 & 30 & 27 \\
\hline & 2005 & PRE & Fine sandy loam & 7.2 & 4.1 & 57 & 25 & 18 \\
\hline & 2005 & POST & Fine sandy loam & 7.2 & 3.8 & 56 & 34 & 20 \\
\hline & 2006 & PRE & Watford/Brady loam & 7.0 & 6.4 & 43 & 30 & 27 \\
\hline & 2006 & POST & Maplewood/Normandale & 6.7 & 5.9 & 35 & 35 & 30 \\
\hline Harrow & $\begin{array}{c}2004 \text { to } \\
2006\end{array}$ & PRE and POST & Fox sandy loam & 6.0 & 2.6 & 83 & 5 & 12 \\
\hline
\end{tabular}

${ }^{\mathrm{a}}$ Abbreviations: PRE, preemergence; POST, postemergence.

Table 2. Mean cumulative precipitation $(\mathrm{mm})$ for day of application and 7 and 14 days before and after PRE and POST herbicide application at Exeter, Harrow, and Ridgetown, Ontario between 2003 and 2006. ${ }^{a}$

\begin{tabular}{|c|c|c|c|c|c|c|c|c|c|c|c|}
\hline \multirow{4}{*}{ Location } & \multirow{4}{*}{ Year } & \multicolumn{10}{|c|}{ Cumulative Precipitation } \\
\hline & & \multicolumn{5}{|c|}{ PRE Herbicides } & \multicolumn{5}{|c|}{ POST Herbicides } \\
\hline & & $\begin{array}{c}14 \\
\text { DBA }\end{array}$ & $7 \mathrm{DBA}$ & $\begin{array}{c}\text { Day of } \\
\text { Application }\end{array}$ & 7 DAA & 14 DAA & 14 DBA & $7 \mathrm{DBA}$ & $\begin{array}{c}\text { Day of } \\
\text { Application }\end{array}$ & $7 \mathrm{DAA}$ & 14 DAA \\
\hline & & \multicolumn{10}{|c|}{$\mathrm{mm}$} \\
\hline \multirow[t]{4}{*}{ Exeter } & 2003 & 29 & 9 & 1 & 39 & 68 & 68 & 29 & 0 & 3 & 8 \\
\hline & 2004 & 89 & 73 & 1 & 5 & 20 & 40 & 25 & 0 & 12 & 24 \\
\hline & 2005 & 22 & 17 & 7 & 0 & 3 & 3 & 0 & 0 & 24 & 35 \\
\hline & 2006 & 16 & 0 & 0 & 12 & 35 & 39 & 11 & 0 & 19 & 19 \\
\hline \multirow[t]{3}{*}{ Harrow } & 2004 & 65 & 27 & 14 & 55 & 64 & 45 & 11 & 0 & 42 & 68 \\
\hline & 2005 & 2 & 0 & 4 & 15 & 22 & 12 & 5 & 0 & 1 & 5 \\
\hline & 2006 & 12 & 10 & 0 & 54 & 69 & 50 & 28 & 0 & 5 & 29 \\
\hline \multirow[t]{4}{*}{ Ridgtetown } & 2003 & 26 & 15 & 0 & 15 & 37 & 60 & 37 & 1 & 18 & 26 \\
\hline & 2004 & 64 & 8 & 0 & 19 & 60 & 35 & 32 & 0 & 29 & 36 \\
\hline & 2005 & 17 & 15 & 0 & 17 & 22 & 18 & 12 & 0 & 4 & 33 \\
\hline & 2006 & 31 & 27 & 0 & 38 & 49 & 39 & 5 & 4 & 18 & 18 \\
\hline
\end{tabular}

${ }^{a}$ Abbreviations: PRE, preemergence; POST, postemergence; DBA, Days before application; DAA, Days after application. 
Table 3. Mean percent control of Chenopodium album in response to preemergence (PRE) herbicides 28 days after treatment (DAT) at Exeter and Ridgetown, Ontario from 2003 to 2006 and Harrow, Ontario from 2005-2006. ${ }^{\mathrm{a}}$

\begin{tabular}{|c|c|c|c|}
\hline \multirow{2}{*}{ Treatment } & \multirow{2}{*}{$\frac{\text { Rate }}{\mathrm{kg} \cdot \mathbf{a i} \cdot \mathrm{ha}^{-1}}$} & \multicolumn{2}{|c|}{ Percent Weed Control } \\
\hline & & Environment $\mathbf{1}^{\mathrm{b}}$ & Environment 2 \\
\hline s-metolachlor/benoxacor/atrazine & 2.88 & $99 \mathrm{a}$ & $67 \mathrm{~b}$ \\
\hline dimethenamid-p + atrazine & $0.75+1.28$ & $100 \mathrm{a}$ & $79 \mathrm{ab}$ \\
\hline isoxaflutole + atrazine & $0.079+0.8$ & $100 \mathrm{a}$ & $78 \mathrm{ab}$ \\
\hline s-metolachlor/benoxacor/atrazine + dicamba & $2.52+0.6$ & $99 \mathrm{a}$ & $87 \mathrm{a}$ \\
\hline dimethenamid + dicamba/atrazine & $1.13+1.48$ & $100 \mathrm{a}$ & $91 \mathrm{a}$ \\
\hline s-metolachlor/benoxacor/atrazine + mesotrione & $2.52+0.14$ & $100 \mathrm{a}$ & $90 \mathrm{a}$ \\
\hline pendimethalin + dicamba/atrazine & $1.68+1.48$ & $99 \mathrm{a}$ & $90 \mathrm{a}$ \\
\hline pendimethalin + atrazine & $1.68+1.53$ & $100 \mathrm{a}$ & $92 \mathrm{a}$ \\
\hline rimsulfuron $+\mathrm{s}$-metolachlor/benoxacor + dicamba & $0.015+0.684+0.36$ & $100 \mathrm{a}$ & $84 \mathrm{a}$ \\
\hline $\mathrm{LSD}_{0.05}$ & & 1.41 & 14.9 \\
\hline
\end{tabular}

${ }^{\mathrm{a}}$ Data were pooled by environment (location and year) when the interaction between environment and treatment was non-significant. Means are presented on the back-transformed scale. Means followed by the same letter within a column are not significantly different according to Fisher's Protected LSD (P $<0.05$ ); ${ }^{b}$ Environment 1: Exeter 2003/2004/2006, Harrow 2005/2006, Ridgetown 2003/2004/2006; Environment 2: Exeter 2005; Ridgetown 2005

Table 4. Mean percent control of Chenopodium album in response to POST herbicides 28 days after treatment (DAT) at Exeter and Ridgetown, Ontario from 2003 to 2006 and Harrow, Ontario from 2005-2006. ${ }^{a}$

\begin{tabular}{|c|c|c|c|}
\hline \multirow{2}{*}{ Treatment $^{\mathrm{b}}$} & \multirow{2}{*}{$\frac{\text { Rate }}{\mathrm{kg} \cdot \mathbf{a i} \cdot \mathrm{ha}^{-1}}$} & \multicolumn{2}{|c|}{ Percent Weed Control } \\
\hline & & Environment $1^{\mathrm{c}}$ & Environment 2 \\
\hline glyphosate & 0.9 & $100 \mathrm{a}$ & $92 b$ \\
\hline glyphosate $f b$ glyphosate & $0.9 f b 0.9$ & $100 \mathrm{a}$ & $99 \mathrm{a}$ \\
\hline rimsulfuron + s-metolachlor/benoxacor + dicamba & $0.0125+0.573+0.3$ & $100 \mathrm{a}$ & $99 \mathrm{a}$ \\
\hline nicosulfuron/rimsulfuron + dicamba/diflufenzopyr ${ }^{\mathrm{d}}$ & $0.025+0.2$ & $98 \mathrm{a}$ & $98 \mathrm{a}$ \\
\hline nicosulfuron/rimsulfuron + mesotrione + atrazine & $0.025+0.1+0.28$ & $99 \mathrm{a}$ & $100 \mathrm{a}$ \\
\hline nicosulfuron + dicamba/diflufenzopyr & $0.025+0.2$ & $94 \mathrm{a}$ & $98 \mathrm{a}$ \\
\hline nicosulfuron + prosulfuron + dicamba & $0.025+0.01+0.14$ & $95 \mathrm{a}$ & $98 \mathrm{a}$ \\
\hline nicosulfuron + mesotrione + atrazine & $0.0025+0.1+0.28$ & $100 \mathrm{a}$ & $99 \mathrm{a}$ \\
\hline nicosulfuron + pendimethalin + dicamba & $0.0125+1.0+0.3$ & $100 \mathrm{a}$ & $100 \mathrm{a}$ \\
\hline nicosulfuron + primisulfuron/dicamba & $0.0188+0.166$ & $100 \mathrm{a}$ & $98 \mathrm{a}$ \\
\hline foramsulfuron + dicamba/diflufenzopyr ${ }^{\mathrm{e}}$ & $0.07+0.2$ & $100 \mathrm{a}$ & $100 \mathrm{a}$ \\
\hline $\mathrm{LSD}_{0.05}$ & & 6.58 & 2.6 \\
\hline
\end{tabular}

${ }^{\mathrm{a}}$ Data were pooled by environment (location and year) when the interaction between environment and treatment was non-significant; Means are presented on the back-transformed scale. Means followed by the same letter within a column are not significantly different according to Fisher's Protected LSD (P < 0.05). Abbreviations: POST, postemergence; $f b$, followed by; ${ }^{b}$ All treatments other than glyphosate and glyphosate $f b$ glyphosate had a non-ionic surfactant added at $0.2 \% \mathrm{v} / \mathrm{v}$; ${ }^{\mathrm{c}}$ Environment 1: Exeter 2003, Harrow 2005; Environment 2: Exeter 2004/2005/2006, Harrow 2006, Ridgetown 2003/2004/2005/2006; ${ }^{\mathrm{d}} \mathrm{UAN}$ 28\% was added to nicosulfuron/rimsulfuron + dicamba/diflufenzopyr; nicosulfuron + dicamba/diflufenzopyr; and foramsulfuron + dicamba/diflufenzopyr treatments at $1.25 \mathrm{~L} \cdot \mathrm{ha}^{-1}$; ${ }^{\mathrm{e}}$ An MSO at $1.75 \mathrm{~L} \cdot \mathrm{ha}^{-1}$ was added to this treatment.

all sites. Percent weed control was visually assessed 28 and 56 days after treatment (DAT) using a scale of 0 to 100 where a rating of 0 was defined as no visible weed control and a rating of 100 was defined as complete control. Only data from 28 DAT are presented in this manuscript. Corn was mechanically harvested at physiological maturity using a plot combine at all sites. Corn yields were adjusted to a $15.5 \%$ moisture level.

All data were subjected to analysis of variance (ANOVA) and analyzed using the PROC MIXED pro- cedure in SAS statistical software [38]. Variances were partitioned into the fixed effect of herbicide treatment and into the random effects of year and location, the interaction of year and location by the fixed effect, and blocks nested within year and location establishing the environment groupings presented in each of the data tables. The assumptions of the variance analysis were tested by ensuring that the residuals were random, homogeneous, with a normal distribution about a mean of zero using residual plots and the Shapiro-Wilk normality 
test. When the interaction between year, location and treatment was not significant, data were pooled by environment. Percent weed control data required an acrsine square-root transformation. Crop yield data did not require transformation. Transformed data were back-transformed for presentation in the tables. Treatment means were separated at the 5\% level of significance using a Fisher's Protected LSD test.

\section{Results and Discussion}

\subsection{Chenopodium album}

A significant treatment by year by location interaction resulted in two distinct environments for Chenopodium album control with PRE herbicides (Table 3) and two distinct environments with POST herbicides (Table 4). Preemergence control of Chenopodium album was near perfect $(>99 \%)$ in environment 1 for all treatments (Table 3); however, control was variable in environment 2 . $S$-metolachlor/benoxacor/atrazine, dimethenamid-p + atrazine, and isoxaflutole + atrazine had lower control of Chenopodium album in environment 2 compared to all other treatments (Table 3). S-metolachlor/benoxacor/ atrazine provided only $67 \%$ control of Chenopodium album in environment 2 , and dimethenamid-p + atrazine or isoxaflutole + atrazine provided less than $80 \%$ control. Because PRE herbicides require precipitation to move into the zone of active seed germination, a decrease in precipitation for May 2005 of up to $59 \%$ of the $30-y r$ average may explain the variability among treatments $(S$ metolachlor/benoxacor/atrazine, isoxaflutole + atrazine, and dimethenamid-p + atrazine) in environment $2[4,17$, 26,29,39]. Additionally, Environment 2 (Exeter 2005) received only $3 \mathrm{~mm}$ of precipitation within 14 DAT (Table 2). The reduced control with isoxaflutole and S-metolachlor is supported by Chomas and Kells [10] who found that when precipitation was limited to $2 \mathrm{~mm} 14 \mathrm{DAT}$, isoxaflutole + atrazine and S-metolachlor + atrazine only controlled Chenopodium album 33\% and 75\%, respectively, in comparison to a weed-free control in corn. In the same study; however, pendimethalin plus atrazine provided 91\% control of Chenopodium album; which is comparable to our observations of $94 \%$ averaged over both environments.

Postemergence control of Chenopodium album in environment 1 was $94 \%$ to $100 \%$ (Table 4). Sequential applications of glyphosate increased Chenopodium album control by $7 \%$ in environment 2 , compared to a single application of glyphosate. Chenopodium album control among the other herbicide treatments in environment 2 only varied by $2 \%$. The efficacy of glyphosate can be reduced if precipitation occurs $15 \mathrm{~min}$ to $6 \mathrm{hr}$ after application depending on formulation [24,25,27]. The formulation of glyphosate used in this study has a rain fast time of $15 \mathrm{~min}$. Therefore, precipitation on the day of glyphosate application (Ridgetown, 2003 and 2006) (Table 2) is unlikely to have contributed to reduced Chenopodium album control.

\subsection{Ambrosia artemisiifolia}

A significant treatment by environment interaction resulted in two distinct environments for Ambrosia artemisiifolia control with PRE herbicides (Table 5) and two distinct environments with POST herbicides (Table 6). Ambrosia artemisiifolia control with PRE herbicides was excellent $(>97 \%)$ in environment 1, but varied among treatments in environment 2 (Table 5). S-metolachlor/benoxacor/atrazine had the lowest control of Ambrosia artemisiifolia compared to any other treatment. Pendimethalin + atrazine had 7\% lower control compared to the dimethenamid + dicamba/atrazine and pendimethalin + dicamba/atrazine treatments, respectively, in environment 2. Poor control with $S$-metolachlor/benoxacor/atrazine and pendimethalin + atrazine alone was expected as neither herbicide provides adequate control of this species $[27,40]$. The addition of dicamba to $S$-metolachlor/benoxacor/atrazine or pendimethalin + atrazine increased the Ambrosia artemisiifolia control already being provided by the atrazine. Rimsulfuron + $S$-metolachlor/benoxacor + dicamba was a tank-mix that provided excellent (100\%) control of Ambrosia artemisiifolia except in environment 2. Exeter and Ridgetown in 2005 (environment 2 ) received $66 \%$ less precipitation in May and June compared to a 30-yr average (data not shown). It is likely that these exceptionally dry conditions contributed to the reduced Ambrosia artemisiifolia control with dicamba because of reduced uptake of the herbicide from the soil.

Postemergence herbicide treatments provided greater than $92 \%$ control of Ambrosia artemisiifolia in both environments (Table 6).

\subsection{Amaranthus retroflexus}

A significant treatment by environment interaction resulted in two distinct environments for Amaranthus retroflexus control with PRE herbicides (Table 7), and two distinct environments for control with POST herbicides (Table 8). Amaranthus retroflexus control did not differ among treatments in environment 1 . In environment 2 , $S$-metolachlor/benoxacor/atrazine and dimethenamid-p + atrazine treatments had lower control compared to all other treatments except pendimethalin + atrazine. Limited precipitation at Ridgetown in 2005 (Table 2) after herbicide application may have contributed to reduced control of this species. Both of these treatments require precipitation to move into the zone of active seed germination $[17,26,39]$. 
Table 5. Mean percent control of Ambrosia artemisiifolia in response to preemergence (PRE) herbicides 28 days after treatment (DAT) at Exeter, Ontario from 2003 to 2006, Ridgetown, Ontario in 2003 and 2006 and Harrow, Ontario in 2004 and 2006. ${ }^{\mathrm{a}}$

\begin{tabular}{|c|c|c|c|}
\hline \multirow{2}{*}{ Treatment } & \multirow{2}{*}{$\begin{array}{c}\text { Rate } \\
\mathrm{kg} \cdot \mathbf{a i} \cdot \mathbf{h a}^{-1}\end{array}$} & \multicolumn{2}{|c|}{ Percent Weed Control } \\
\hline & & Environment $1^{\mathrm{y}}$ & Environment 2 \\
\hline s-metolachlor/benoxacor/atrazine & 2.88 & $100 \mathrm{a}$ & $77 \mathrm{~b}$ \\
\hline dimethenamid-p + atrazine & $0.75+1.28$ & $100 \mathrm{a}$ & $93 \mathrm{a}$ \\
\hline isoxaflutole + atrazine & $0.079+0.8$ & $97 \mathrm{a}$ & $83 \mathrm{ab}$ \\
\hline s-metolachlor/benoxacor/atrazine + dicamba & $2.52+0.6$ & $100 \mathrm{a}$ & $98 \mathrm{a}$ \\
\hline dimethenamid + dicamba/atrazine & $1.13+1.48$ & $100 \mathrm{a}$ & $98 \mathrm{a}$ \\
\hline s-metolachlor/benoxacor/atrazine + mesotrione & $2.52+0.14$ & $100 \mathrm{a}$ & $94 \mathrm{a}$ \\
\hline pendimethalin + dicamba/atrazine & $1.68+1.48$ & $100 \mathrm{a}$ & $98 \mathrm{a}$ \\
\hline pendimethalin + atrazine & $1.68+1.53$ & $100 \mathrm{a}$ & $91 \mathrm{a}$ \\
\hline rimsulfuron $+\mathrm{s}$-metolachlor/benoxacor + dicamba & $0.015+0.684+0.36$ & $100 \mathrm{a}$ & $86 a b$ \\
\hline $\mathrm{LSD}_{0.05}$ & & 3.11 & 15.97 \\
\hline
\end{tabular}

${ }^{\mathrm{a}}$ Data were pooled by environment (location and year) when the interaction between environment and treatment was non-significant. Means are presented on the back-transformed scale. Means followed by the same letter within a column are not significantly different according to Fisher's Protected LSD (P < 0.05); ${ }^{b}$ Environment 1: Exeter 2003/2004/2006, Harrow 2004/2006, Ridgetown 2003/2006; Environment 2: Exeter 2005 ; Ridgetown 2005.

Table 6. Mean percent control of Ambrosia artemisiifolia in response to POST herbicides 28 days after treatment (DAT) at Exeter and Ridgetown, Ontario from 2003 to 2006 and Harrow, Ontario from 2005 and $2006 .{ }^{a}$

\begin{tabular}{|c|c|c|c|}
\hline \multirow{2}{*}{ Treatment $^{\mathrm{b}}$} & \multirow{2}{*}{$\frac{\text { Rate }}{\mathrm{kg} \cdot \mathbf{a} \cdot \mathbf{h a a}^{-1}}$} & \multicolumn{2}{|c|}{ Percent Weed Control } \\
\hline & & Environment $1^{\mathrm{c}}$ & Environment 2 \\
\hline glyphosate & 0.9 & $100 \mathrm{a}$ & $92 \mathrm{~b}$ \\
\hline glyphosate $f b$ glyphosate & $0.9 f b 0.9$ & $100 \mathrm{a}$ & $100 \mathrm{a}$ \\
\hline rimsulfuron $+\mathrm{s}$-metolachlor/benoxacor + dicamba & $0.0125+0.573+0.3$ & $100 \mathrm{a}$ & $100 \mathrm{a}$ \\
\hline nicosulfuron/rimsulfuron + dicamba/diflufenzopyr ${ }^{d}$ & $0.025+0.2$ & $99 \mathrm{a}$ & $100 \mathrm{a}$ \\
\hline nicosulfuron/rimsulfuron + mesotrione + atrazine & $0.025+0.1+0.28$ & $99 \mathrm{a}$ & $100 \mathrm{a}$ \\
\hline nicosulfuron + dicamba/diflufenzopyr & $0.025+0.2$ & $99 \mathrm{a}$ & $100 \mathrm{a}$ \\
\hline nicosulfuron + prosulfuron + dicamba & $0.025+0.01+0.14$ & $99 \mathrm{a}$ & $100 \mathrm{a}$ \\
\hline nicosulfuron + mesotrione + atrazine & $0.0025+0.1+0.28$ & $99 \mathrm{a}$ & $100 \mathrm{a}$ \\
\hline nicosulfuron + pendimethalin + dicamba & $0.0125+1.0+0.3$ & $100 \mathrm{a}$ & $100 \mathrm{a}$ \\
\hline nicosulfuron + primisulfuron/dicamba & $0.0188+0.166$ & $100 \mathrm{a}$ & $100 \mathrm{a}$ \\
\hline foramsulfuron + dicamba/diflufenzopyr ${ }^{\mathrm{e}}$ & $0.07+0.2$ & $99 a$ & $100 \mathrm{a}$ \\
\hline $\mathrm{LSD}_{0.05}$ & & 2.19 & 1.99 \\
\hline
\end{tabular}

${ }^{a}$ Data were pooled by environment (location and year) when the interaction between environment and treatment was non-significant. Means are presented on the back-transformed scale. Means followed by the same letter within a column are not significantly different according to Fisher's Protected LSD (P $<0.05$ ). Abbreviations: POST, postemergence; $f b$, followed by; ${ }^{\mathrm{b}}$ All treatments other than glyphosate and glyphosate $f b$ glyphosate had a non-ionic surfactant added at $0.2 \% \mathrm{v} / \mathrm{v}$; ${ }^{\circ}$ Environment 1: Exeter 2003, Harrow 2005, Ridgetown 2005/2006; Environment 2: Exeter 2004/2005/2006, Harrow 2004/2006, Ridgetown $2003 / 2004 ;$ d UAN $28 \%$ was added to nicosulfuron/rimsulfuron + dicamba/diflufenzopyr; nicosulfuron + dicamba/diflufenzopyr; and foramsulfuron + dicamba/ diflufenzopyr treatments at $1.25 \mathrm{~L} \cdot \mathrm{ha}^{-1} ;{ }^{\mathrm{e}} \mathrm{An} \mathrm{MSO}$ at $1.75 \mathrm{~L} \cdot \mathrm{ha}^{-1}$ was added to this treatment. 
Table 7. Mean percent control of Amaranthus retroflexus in response to preemergence (PRE) herbicides 28 days after treatment (DAT) at Exeter, Ontario from 2003 to 2006, Ridgetown, Ontario from 2004 to 2005 and Harrow, Ontario in 2006.

\begin{tabular}{lccc}
\hline \multirow{2}{*}{ Treatment } & Rate & \multicolumn{2}{c}{ Percent Weed Control } \\
\cline { 2 - 4 } & $\mathbf{k g} \cdot \mathbf{a i} \cdot \mathbf{h a}^{-\mathbf{1}}$ & Environment 1 $^{\mathbf{b}}$ & Environment 2 \\
\hline s-metolachlor/benoxacor/atrazine & 2.88 & $99 \mathrm{a}$ & $56 \mathrm{c}$ \\
dimethenamid-p + atrazine & $0.75+1.28$ & $100 \mathrm{a}$ & $75 \mathrm{bc}$ \\
isoxaflutole + atrazine & $0.079+0.8$ & $99 \mathrm{a}$ & $97 \mathrm{a}$ \\
s-metolachlor/benoxacor/atrazine + dicamba & $2.52+0.6$ & $100 \mathrm{a}$ & $100 \mathrm{a}$ \\
dimethenamid + dicamba/atrazine & $1.13+1.48$ & $100 \mathrm{a}$ & $100 \mathrm{a}$ \\
s-metolachlor/benoxacor/atrazine + mesotrione & $2.52+0.14$ & $100 \mathrm{a}$ & $100 \mathrm{a}$ \\
pendimethalin + dicamba/atrazine & $1.68+1.48$ & $100 \mathrm{a}$ & $100 \mathrm{a}$ \\
pendimethalin + atrazine & $1.68+1.53$ & $100 \mathrm{a}$ & $84 \mathrm{ab}$ \\
rimsulfuron + s-metolachlor/benoxacor + dicamba & $0.015+0.684+0.36$ & $100 \mathrm{a}$ & 1.53 \\
LSD $_{0.05}$ & & $100 \mathrm{a}$ \\
\hline
\end{tabular}

${ }^{\mathrm{a}}$ Data were pooled by environment (location and year) when the interaction between environment and treatment was non-significant. Means are presented on the back-transformed scale. Means followed by the same letter within a column are not significantly different according to Fisher's Protected LSD (P $<0.05$ ); ${ }^{\mathrm{b}}$ Environment 1: Exeter 2003/2004/2005/2006, Harrow 2006, Ridgetown 2004; Environment 2: Ridgetown 2005.

Table 8. Mean percent control of Amaranthus retroflexus in response to POST herbicides 28 days after treatment (DAT) at Exeter, Ontario from 2003 to 2006, Ridgetown, Ontario in 2003, 2004 and 2006 and Harrow, Ontario in $2006 .{ }^{a}$

\begin{tabular}{|c|c|c|c|}
\hline \multirow{2}{*}{ Treatment $^{\mathrm{b}}$} & \multirow{2}{*}{$\begin{array}{c}\text { Rate } \\
\mathrm{kg} \cdot \mathbf{a i} \cdot \mathrm{ha}^{-1}\end{array}$} & \multicolumn{2}{|c|}{ Percent Weed Control } \\
\hline & & Environment $1^{\mathrm{c}}$ & Environment 2 \\
\hline glyphosate & 0.9 & $100 \mathrm{a}$ & $91 b$ \\
\hline glyphosate $f b$ glyphosate & $0.9 f b 0.9$ & $99 \mathrm{a}$ & $98 \mathrm{ab}$ \\
\hline rimsulfuron + s-metolachlor/benoxacor + dicamba & $0.0125+0.573+0.3$ & $100 \mathrm{a}$ & $96 \mathrm{ab}$ \\
\hline nicosulfuron/rimsulfuron + dicamba/diflufenzopyr ${ }^{\mathrm{d}}$ & $0.025+0.2$ & $100 \mathrm{a}$ & $99 \mathrm{a}$ \\
\hline nicosulfuron/rimsulfuron + mesotrione + atrazine & $0.025+0.1+0.28$ & $99 \mathrm{a}$ & $96 \mathrm{ab}$ \\
\hline nicosulfuron + dicamba/diflufenzopyr & $0.025+0.2$ & $100 \mathrm{a}$ & $99 \mathrm{a}$ \\
\hline nicosulfuron + prosulfuron + dicamba & $0.025+0.01+0.14$ & $100 \mathrm{a}$ & $98 \mathrm{ab}$ \\
\hline nicosulfuron + mesotrione + atrazine & $0.0025+0.1+0.28$ & $99 \mathrm{a}$ & $93 b$ \\
\hline nicosulfuron + pedimethalin + dicamba & $0.0125+1.0+0.3$ & $99 \mathrm{a}$ & $98 \mathrm{ab}$ \\
\hline nicosulfuron + primisulfuron/dicamba & $0.0188+0.166$ & $100 \mathrm{a}$ & $99 \mathrm{a}$ \\
\hline foramsulfuron + dicamba/diflufenzopyr ${ }^{\mathrm{e}}$ & $0.07+0.2$ & $100 \mathrm{a}$ & $100 \mathrm{a}$ \\
\hline $\mathrm{LSD}_{0.05}$ & & 1.10 & 5.78 \\
\hline
\end{tabular}

${ }^{a}$ Data were pooled by environment (location and year) when the interaction between environment and treatment was non-significant. Means are presented on the back-transformed scale. Means followed by the same letter within a column are not significantly different according to Fisher's Protected LSD (P $<0.05)$. Abbreviations: POST, postemergence; $f b$, followed by; ${ }^{b}$ All treatments other than glyphosate and glyphosate $f b$ glyphosate had a non-ionic surfactant added at $0.2 \% \mathrm{v} / \mathrm{v}$; ${ }^{\mathrm{c}}$ Environment 1: Exeter 2003/2004/2005; Environment 2: Exeter 2006, Harrow 2006, Ridgetown 2003/2004/2006; ${ }^{\mathrm{d}}{ }^{\mathrm{UAN}} 28 \%$ was added to nicosulfuron/rimsulfuron + dicamba/diflufenzopyr; nicosulfuron + dicamba/diflufenzopyr; and foramsulfuron + dicamba/diflufenzopyr treatments at $1.25 \mathrm{~L} \cdot \mathrm{ha}^{-1}$; ${ }^{\mathrm{e}} \mathrm{An} \mathrm{MSO}$ at $1.75 \mathrm{~L} \cdot \mathrm{ha}^{-1}$ was added to this treatment.

Control of Amaranthus retroflexus did not differ among POST treatments in environment 1. Sequential applications of glyphosate provided an increase in Amaranthus retroflexus control by up to $7 \%$ compared to a single application in environment 2. Amaranthus retroflexus control varied by up to $7 \%$ among treatments in environment 2, except for treatment 1 where control was $9 \%$ lower. Control of Amaranthus retroflexus was reduced when nicosulfuron + mesotrione + atrazine was applied compared to nicosulfuron/rimsulfuron + dicamba/diflufenzopyr, nicosulfuron + dicamba/diflufenzopyr and foramsulfuron + dicamba/diflufenzopyr. Mesotrione plus atrazine (POST) can be antagonistic when tank-mixed with sulfonylureas such as nicosulfuron, but to-date this has only been shown to affect control of annual grass species $[7,41,42]$. 


\subsection{Setaria viridis}

A significant treatment by environment interaction resulted in three distinct environments for Setaria viridis control with PRE herbicides (Table 9) and two distinct environments for POST herbicides (Table 10). For PRE herbicides, there was little variability among treatments in environment 3 . In environment 1 , Setaria viridis control was the lowest with pendimethalin + dicamba/ atrazine (Table 9). This result can be attributed to the high amount of precipitation received. Exeter received 68 $\mathrm{mm}$ of precipitation in 2003 and Ridgetown received 49 $\mathrm{mm}$ in 2006 during the 14 DAT (Table 2), representing 87 and $64 \%$ of the 30 -year norm for the entire month of May, respectively (data not shown). Pendimethalin is more persistent under dry conditions [31] and can leach with $20 \mathrm{~mm}$ of precipitation in turfgrass [30]. Atrazine also has the potential to leach with relatively low levels of precipitation [25].

Table 9. Mean percent control of Setaria viridis in response to preemergence (PRE) herbicides 28 days after treatment (DAT) at Exeter, Ontario from 2003 to 2006, Ridgetown, Ontario from 2004 to 2006 and Harrow, Ontario from 2005 to $2006 .{ }^{\text {a }}$

\begin{tabular}{|c|c|c|c|c|}
\hline \multirow{2}{*}{ Treatment } & \multirow{2}{*}{$\begin{array}{l}\text { Rate } \\
\mathrm{kg} \cdot \mathrm{ai} \cdot \mathrm{ha}^{-1}\end{array}$} & \multicolumn{3}{|c|}{$\begin{array}{r}\text { Percent Weed Control } \\
\end{array}$} \\
\hline & & Environment $1^{\text {b }}$ & Environment 2 & Environment 3 \\
\hline s-metolachlor/benoxacor/atrazine & 2.88 & $96 \mathrm{ab}$ & $76 \mathrm{a}$ & $97 \mathrm{a}$ \\
\hline dimethenamid-p + atrazine & $0.75+1.28$ & $99 \mathrm{a}$ & $81 \mathrm{a}$ & $100 \mathrm{a}$ \\
\hline isoxaflutole + atrazine & $0.079+0.8$ & $99 \mathrm{a}$ & $46 b$ & $100 \mathrm{a}$ \\
\hline s-metolachlor/benoxacor/atrazine + dicamba & $2.52+0.6$ & $97 \mathrm{ab}$ & $85 \mathrm{a}$ & $100 \mathrm{a}$ \\
\hline s-metolachlor/benoxacor/atrazine + mesotrione & $2.52+0.14$ & $96 \mathrm{ab}$ & $79 \mathrm{a}$ & $100 \mathrm{a}$ \\
\hline pendimethalin + dicamba/atrazine & $1.68+1.48$ & $84 b$ & $85 \mathrm{a}$ & $100 \mathrm{a}$ \\
\hline pendimethalin + atrazine & $1.68+1.53$ & $95 \mathrm{ab}$ & $76 \mathrm{a}$ & $100 \mathrm{a}$ \\
\hline rimsulfuron + s-metolachlor/benoxacor + dicamba & $0.015+0.684+0.36$ & $98 \mathrm{a}$ & $79 \mathrm{a}$ & $98 \mathrm{a}$ \\
\hline $\mathrm{LSD}_{0.05}$ & & 13.81 & 17.24 & 3.86 \\
\hline
\end{tabular}

${ }^{\mathrm{a}}$ Data were pooled by environment (location and year) when the interaction between environment and treatment was non-significant. Means are presented on the back-transformed scale. Means followed by the same letter within a column are not significantly different according to Fisher's Protected LSD (P < 0.05); ${ }^{\mathrm{b}}$ Environment 1: Exeter 2003, Ridgetown 2006; Environment 2: Exeter 2004/2005, Ridgetown 2005; Environment 3: Exeter 2006, Harrow 2005/2006, Ridgetown 2004

Table 10. Mean percent control of Setaria viridis in response to POST herbicides 28 days after treatment (DAT) at Exeter, Ontario from 2003 to 2006 and Ridgetown, Ontario from 2003 to $2005 .{ }^{a}$

\begin{tabular}{|c|c|c|c|}
\hline \multirow{3}{*}{ Treatment $^{b}$} & \multirow{3}{*}{$\begin{array}{l}\text { Rate } \\
\mathbf{k g} \cdot \mathbf{a i} \cdot \mathbf{h a}^{-1}\end{array}$} & \multicolumn{2}{|c|}{ Percent Weed Control } \\
\hline & & Environment $1^{\mathrm{c}}$ & Environment 2 \\
\hline & & \multicolumn{2}{|c|}{ MT ha $^{-1}$} \\
\hline glyphosate & 0.9 & $97 \mathrm{ab}$ & $78 \mathrm{e}$ \\
\hline glyphosate $f b$ glyphosate & $0.9 f b 0.9$ & $100 \mathrm{a}$ & $96 \mathrm{a}$ \\
\hline rimsulfuron + s-metolachlor/benoxacor + dicamba & $0.0125+0.573+0.3$ & $93 b$ & $83 d$ \\
\hline nicosulfuron/rimsulfuron + dicamba/diflufenzopyr ${ }^{\mathrm{d}}$ & $0.025+0.2$ & $98 \mathrm{a}$ & $89 b$ \\
\hline nicosulfuron/rimsulfuron + mesotrione + atrazine & $0.025+0.1+0.28$ & $96 \mathrm{ab}$ & $87 \mathrm{bc}$ \\
\hline nicosulfuron + dicamba/diflufenzopyr & $0.025+0.2$ & $96 \mathrm{ab}$ & $88 \mathrm{bc}$ \\
\hline nicosulfuron + prosulfuron + dicamba & $0.025+0.01+0.14$ & $97 \mathrm{ab}$ & $87 \mathrm{bc}$ \\
\hline nicosulfuron + mesotrione + atrazine & $0.0025+0.1+0.28$ & $95 \mathrm{ab}$ & $87 \mathrm{bc}$ \\
\hline nicosulfuron + primisulfuron/dicamba & $0.0188+0.166$ & $97 \mathrm{ab}$ & $89 b$ \\
\hline foramsulfuron + dicamba/diflufenzopyr ${ }^{\mathrm{e}}$ & $0.07+0.2$ & $96 \mathrm{ab}$ & $90 b$ \\
\hline $\mathrm{LSD}_{0.05}$ & & 5.42 & 4.25 \\
\hline
\end{tabular}

${ }^{\mathrm{a}}$ Data were pooled by environment (location and year) when the interaction between environment and treatment was non-significant. Means are presented on the back-transformed scale. Means followed by the same letter within a column are not significantly different according to Fisher's Protected LSD (P < 0.05). Abbreviations: POST, postemergence; $f b$, followed by; ${ }^{\mathrm{b}}$ All treatments other than glyphosate and glyphosate $f b$ glyphosate had a non-ionic surfactant added at $0.2 \% \mathrm{v} / \mathrm{v}$; ${ }^{\mathrm{c}}$ Environment 1: Exeter 2003/2004/2006, Ridgetown 2003/2005; Environment 2: Exeter 2005, Ridgetown 2004; ${ }^{\mathrm{d} U A N} 28 \%$ was added to nicosulfuron/rimsulfuron + dicamba/diflufenzopyr; nicosulfuron + dicamba/diflufenzopyr; and foramsulfuron + dicamba/diflufenzopyr treatments at 1.25 L $\cdot$ ha ${ }^{-1}$; ${ }^{\mathrm{e}}$ An MSO at $1.75 \mathrm{~L} \cdot \mathrm{ha}^{-1}$ was added to this treatment. 
In environment 2, isoxaflutole + atrazine provided $46 \%$ control of Setaria viridis, while all other treatments had $76 \%$ or better control. Low levels of precipitation 7 DAT at Exeter in 2004 contributed to reduced control, because isoxaflutole + atrazine requires precipitation for activation [29].

Control of Setaria viridis with POST herbicides varied among treatments in both environments (Table 10). Rimsulfuron $+S$-metolachlor/benoxacor + dicamba reduced Setaria viridis control by $5 \%$ compared to nicosulfuron/rimsulfuron + dicamba/diflufenzopyr in environment 1 . The slight decrease in control can be attributed to delayed precipitation for 2 - 4 DAT at Exeter (2003, 2006) and Ridgetown (2003, 2005). Similar results were illustrated by Lyon and Wilson [4].

With the exception of sequential applications of glyphosate, all treatments in environment 2 provided $90 \%$ or less control of Setaria viridis. Precipitation at Exeter in May and June 2005 was $41 \%$ and $55 \%$ of the monthly norm, respectively (data not shown). Dry conditions at Exeter in 2005 may have lead to reduced control through decreased herbicide translocation and uptake. Morton and Harvey [43] found similar results with primisulfuron applied POST on quackgrass (Elytrigia repens L. Nevski.) in dry conditions (no moisture 6 - 8 days before application) and attributed the result to reduced translocation. Bailey et al. [21] attributed reduced control of yellow nutsedge (Cyperus esculentus L.) with POST applied metribuzin + rimsulfuron to abnormally low precipitation amounts prior to POST application. Additionally, $59 \mathrm{~mm}$ of precipitation was received 14DAT, which may have promoted late emergence of Setaria viridis. Nicosulfuron, foramsulfuron and glyphosate do not have residual con- trol, therefore would not have controlled late emerging weeds [27,34]. Sequential applications of glyphosate had $18 \%$ greater control of Setaria viridis than a single application of glyphosate in environment 2 (Table 10).

\subsection{Corn Yield}

A significant treatment by environment interaction resulted in two distinct environments for corn yield with PRE herbicides (Table 11). Corn yield did not differ among herbicide treatments in environment 1 . Corn yield was reduced with $S$-metolachlor/benoxacor/atrazine, dimethenamid-p + atrazine and pendimethalin + atrazine compared to isoxaflutole + atrazine and $S$-metolachlor/ benoxacor/atrazine + mesotrione in environment 2 . The above results are not linked to reduced weed control. Therefore, the reason for the decrease in yield is unclear.

In environment 2, S-metolachlor/benoxacor/atrazine and $S$-metolachlor/benoxacor/atrazine + mesotrione had the lowest amount of corn yield compared to all other herbicide treatments. Dimethenamid-p + atrazine and pendimethalin + atrazine treatments also had reduced corn yield and this reduced corn yield coincided with reduced weed control at each location for these treatments.

A significant treatment by environment interaction resulted in two distinct environments for corn yield with POST herbicides (Table 12). There was no variation among herbicide treatments in environment 2 and only a slight variation among treatments in environment 1 . Corn yield with nicosulfuron + prosulfuron + dicamba was reduced by $0.5-0.8 \mathrm{~T} \cdot \mathrm{ha}^{-1}$ compared to six other treatments, which corresponds to $3 \%$ and $6 \%$ reduction in Chenopodium album and Setaria viridis control, respecttively (Table 12).

Table 11. Mean corn yield in the untreated check and in response to application of preemergence (PRE) herbicides at Exeter and Ridgetown, Ontario from 2003 to 2006 and Harrow, Ontario from 2004 to 2006. ${ }^{\mathrm{a}}$

\begin{tabular}{|c|c|c|c|}
\hline \multirow{3}{*}{ Treatment } & \multirow{3}{*}{$\begin{array}{l}\text { Rate } \\
\mathrm{kg} \cdot \mathrm{ai} \cdot \mathrm{ha}^{-1}\end{array}$} & \multicolumn{2}{|c|}{ Yield } \\
\hline & & Environment $1^{\text {b }}$ & Environment 2 \\
\hline & & \multicolumn{2}{|c|}{ MT ha $^{-1}$} \\
\hline Untreated Check & & $5.0 \mathrm{~b}$ & $2.5 \mathrm{e}$ \\
\hline s-metolachlor/benoxacor/atrazine & 2.88 & $9.9 \mathrm{a}$ & $6.8 \mathrm{~d}$ \\
\hline dimethenamid-p + atrazine & $0.75+1.28$ & $9.9 \mathrm{a}$ & $8.5 \mathrm{c}$ \\
\hline isoxaflutole + atrazine & $0.079+0.8$ & $10.7 \mathrm{a}$ & $8.9 \mathrm{abc}$ \\
\hline s-metolachlor/benoxacor/atrazine + dicamba & $2.52+0.6$ & $10.5 \mathrm{a}$ & $9.9 \mathrm{ab}$ \\
\hline dimethenamid + dicamba/atrazine & $1.13+1.48$ & $10.6 \mathrm{a}$ & $10.2 \mathrm{a}$ \\
\hline s-metolachlor/benoxacor/atrazine + mesotrione & $2.52+0.14$ & $10.9 \mathrm{a}$ & $7.2 \mathrm{~d}$ \\
\hline pendimethalin + dicamba/atrazine & $1.68+1.48$ & $10.7 \mathrm{a}$ & $10.1 \mathrm{a}$ \\
\hline pendimethalin + atrazine & $1.68+1.53$ & $10.2 \mathrm{a}$ & $8.6 \mathrm{bc}$ \\
\hline rimsulfuron + s-metolachlor/benoxacor + dicamba & $0.015+0.684+0.36$ & $10.3 \mathrm{a}$ & $9.4 \mathrm{abc}$ \\
\hline $\mathrm{LSD}_{0.05}$ & & 1.39 & 1.28 \\
\hline
\end{tabular}

${ }^{\mathrm{a}}$ Data were pooled by environment (location and year) when the interaction between environment and treatment was non-significant. Means followed by the same letter within a column are not significantly different according to Fisher's Protected LSD (P < 0.05); ${ }^{\mathrm{b}}$ Environment 1 : Exeter 2003/2004/2006, Ridgetown 2003/2005/2006, Harrow 2004/2005/2006, Ridgetown 2004; Environment 2: Exeter 2005. 
Table 12. Mean corn yield in the untreated check and in response to application of POST herbicides at Exeter and Ridgetown, Ontario from 2003 to 2006 and Harrow, Ontario from 2004 to 2006. ${ }^{\text {a }}$

\begin{tabular}{|c|c|c|c|}
\hline \multirow[t]{2}{*}{ Treatment $^{\mathrm{b}}$} & \multirow{2}{*}{$\begin{array}{l}\text { Rate } \\
\mathrm{kg} \cdot \mathrm{ai} \cdot \mathrm{ha}^{-1}\end{array}$} & \multicolumn{2}{|c|}{ Yield } \\
\hline & & Environment $1^{\mathrm{c}}$ & Environment 2 \\
\hline & & \multicolumn{2}{|c|}{$\mathrm{MT} \mathrm{ha}^{-1}$} \\
\hline Untreated Check & & $4.7 \mathrm{c}$ & $5.2 b$ \\
\hline glyphosate & 0.9 & $10.0 \mathrm{ab}$ & $12.2 \mathrm{a}$ \\
\hline glyphosate $f b$ glyphosate & $0.9 f b 0.9$ & $10.2 \mathrm{a}$ & $12.3 \mathrm{a}$ \\
\hline rimsulfuron $+\mathrm{s}$-metolachlor/benoxacor + dicamba & $0.0125+0.573+0.3$ & $10.1 \mathrm{ab}$ & $11.9 \mathrm{a}$ \\
\hline nicosulfuron/rimsulfuron + dicamba/diflufenzopyr ${ }^{d}$ & $0.025+0.2$ & $10.5 \mathrm{a}$ & $11.5 \mathrm{a}$ \\
\hline nicosulfuron/rimsulfuron + mesotrione + atrazine & $0.025+0.1+0.28$ & $10.5 \mathrm{a}$ & $11.7 \mathrm{a}$ \\
\hline nicosulfuron + dicamba/diflufenzopyr & $0.025+0.2$ & $10.2 \mathrm{a}$ & $12.1 \mathrm{a}$ \\
\hline nicosulfuron + prosulfuron + dicamba & $0.025+0.01+0.14$ & $9.7 b$ & $12.1 \mathrm{a}$ \\
\hline nicosulfuron + mesotrione + atrazine & $0.0025+0.1+0.28$ & $10.4 \mathrm{a}$ & $11.9 \mathrm{a}$ \\
\hline nicosulfuron + pedimethalin + dicamba & $0.0125+1.0+0.3$ & $10.1 \mathrm{ab}$ & $11.8 \mathrm{a}$ \\
\hline nicosulfuron + primisulfuron/dicamba & $0.0188+0.166$ & $9.9 \mathrm{ab}$ & $11.7 \mathrm{a}$ \\
\hline foramsulfuron + dicamba/diflufenzopyr ${ }^{\mathrm{e}}$ & $0.07+0.2$ & $10.2 \mathrm{a}$ & $11.1 \mathrm{a}$ \\
\hline $\mathrm{LSD}_{0.05}$ & & 0.47 & 2.1 \\
\hline
\end{tabular}

${ }^{a}$ Data were pooled by environment (location and year) when the interaction between environment and treatment was non-significant. Means followed by the same letter within a column are not significantly different according to Fisher's Protected LSD (P $<0.05)$. Abbreviations: POST, postemergence; fb, followed by; ${ }^{b}$ All treatments other than glyphosate and glyphosate $f b$ glyphosate had a non-ionic surfactant added at $0.2 \%$ v/v; ${ }^{\mathrm{c}}$ Environment 1 : Exeter $2003 / 2004 / 2005$, Ridgetown 2005; Environment 2: Exeter 2006, Harrow 2004/2005/2006, Ridgetown 2003/2004/2006; ${ }^{\mathrm{d}}$ UAN $28 \%$ was added to nicosulfuron/rimsulfuron + dicamba/diflufenzopyr; nicosulfuron + dicamba/diflufenzopyr; and foramsulfuron + dicamba/diflufenzopyr treatments at $1.25 \mathrm{~L} \cdot \mathrm{ha}^{-1}$; ${ }^{\mathrm{e}}$ An $\mathrm{MSO}$ at $1.75 \mathrm{~L} \cdot \mathrm{ha}{ }^{-1}$ was added to this treatment.

\section{Conclusion}

Results demonstrate that the efficacy of PRE and POST herbicides are affected by the timing and amount of precipitation. Limited precipitation 7 days before or after herbicide application can reduce efficacy of PRE herbicides that require precipitation for optimal activity and excessive precipitation may delay POST herbicide application allowing weeds to grow beyond an optimal size. Additionally, precipitation on the day of PRE herbicide application or precipitation 14 DAT that is greater than $50 \%$ of the monthly average can cause some herbicides to leach (i.e. atrazine and pendimethalin), resulting in reduced efficacy. Therefore, precipitation amount and timing should be considered when selecting the most appropriate weed management strategy in corn. A further objective of this study was to determine if a glyphosate only program would be provide more sustainable weed control than a mixed mode of action program under variable precipitation. These data suggest that two sequential applications of glyphosate was the most consistent weed management program for postemergence control of weeds. However, with careful monitoring of precipitation and other climatic conditions the authors recommend the incorporation of other modes of action to ensure proper herbicide resistance management.

\section{Acknowledgements}

The authors wish to acknowledge the technical assistance of Todd Cowan, Christy Shropshire, and Mac Whaley. Funding for this research was provided by BASF, Bayer CropScience, Dow Agrosciences, Dupont, Monsanto, and Syngenta Crop Protection

\section{REFERENCES}

[1] G. R. Armel, H. P. Wilson, R. J. Richardson and T. E. Hines, "Mesotrione, Acetochlor, and Atrazine for Weed Management in Corn (Zea mays)," Weed Technology, Vol. 17, No. 2, 2003, pp. 284-290. doi:10.1614/0890-037X(2003)017[0284:MAAAFW]2.0. $\mathrm{CO} ; 2$

[2] J. A. Bond and J. L. Griffin, "Weed Control in Corn (Zea mays) with an Imazethapyr plus Imazapyr Prepackaged Mixture," Weed Technology, Vol. 19, No. 4, 2005, pp. 992-998. doi:10.1614/WT-04-267R1.1

[3] A. R. Isensee and A. M. Sadeghi, "Effects of Tillage and Rainfall on Atrazine Residue Levels in Soil," Weed Science, Vol. 42, No. 3, 1994, pp. 462-467.

[4] D. J. Lyon and R. G. Wilson, "Chemical Weed Control in Dryland and Irrigated Chickpea," Weed Technology, Vol. 19, No. 4, 2005, pp. 959-965. doi:10.1614/WT-05-013R.1 
[5] C. L. Stewart, R. E. Nurse, A. S. Hamill and P. H. Sikkema, "Environment and Soil Conditions Influence Preand Post-Emergence Herbicide Efficacy in Soybean," Weed Technology, Vol. 24, No. 3, 2010, pp. 234-243. doi:10.1614/WT-09-009.1

[6] M. A. Ferrell, T. D. Whitson and S. D. Miller, "Basic Guide to Weeds and Herbicides," The University of Wyoming, College of Agriculture, Department of Plant Sciences, Cooperative Extension Service, MP18, 2004, pp. 1-19.

[7] C. A. Damalas, and I. G. Eleftherohorinos, "Dicamba and Atrazine Antagonism on Sulfonylurea Herbicides Used for Johnsongrass (Sorghum halepense) Control in Corn (Zea mays)," Weed Technology, Vol. 15, No. 1, 2001, pp. 62-67.

doi:10.1614/0890-037X(2001)015[0062:DAAAOS]2.0.C $\underline{\mathrm{O} ; 2}$

[8] D. L. Jordan, R. E. Frans and M. R. McClelland, "Interactions of DPXPE350 with fluazifop-P, Sethoxydim, Clethodim, and Quizalofop-P," Weed Technology, Vol. 7, 1993, pp. 605-610.

[9] W. A. Pline, J. W. Wilcut and K. L. Edmisten, Postemergence Weed Control in Soybean (Glycine max) with Cloransulam-Methyl and Diphenyl Ether Tank-Mixtures," Weed Technology, Vol. 16, No. 4, 2002, pp. 737-742. doi:10.1614/0890-037X(2002)016[0737:PWCISG]2.0.C $\underline{\mathrm{O} ; 2}$

[10] A. J. Chomas and J. J. Kells, "Triazine-Resistant Common Lambsquarters (Chenopodium album) Control in Corn with Preemergence Herbicides," Weed Technology, Vol. 18, No. 3, 2004, pp. 551-554. doi:10.1614/WT-03-077R

[11] M. M. Loux, A. F. Dobbels, W. G. Johnson, G. R. W Nice, T. T Bauman and J. M. Stachler, "Weed Control Guide for Ohio and Indiana," Ohio State University Extension Bulletin 789/Purdue Extension Pub No. WS16, 2008, $201 \mathrm{p}$.

[12] C. M. Whaley, G. R. Armel, H. P. Wilson and T. E. Hines, "Comparison of Mesotrione Combinations with Standard Weed Control Programs in Corn," Weed Technology, Vol. 20, No. 3, 2006, pp. 605-611. doi:10.1614/WT-05-042R1.1

[13] A. Hager and K. Renner, "Common Ragweed (Ambrosia artemisiifolia) Control in Soybean (Glycine max) with Bentazon as Influenced by Imazethapyr or Thifensulfuron Tank-Mixes," Weed Technology, Vol. 8, No. 4, 1994, pp. 766-771.

[14] S. A. Gower, M. M. Loux, J. Cardina and S. K. Harrison, "Effect of Planting Date, Residual Herbicide, and Postemergence Application Timing on Weed Control and Grain Yield in Glyphosate-Tolerant Corn (Zea mays)," Weed Technology, Vol. 16, No. 3, 2002, pp. 488-494. doi:10.1614/0890-037X(2002)016[0488:EOPDRH]2.0.C $\underline{\mathrm{O} ; 2}$

[15] F. J. Muehlbauer, R. J. Summerfield, W. J. Kaiser, S. L. Clement, C. M. Boerboom, M. M. Welsh-Maddux and R. W. Short, "Principles and Practice of Lentil Production," 1998, Accessed on 1 June 2012. http://www.ars.usda.gov/is/np/lentils/lentils.htm?pf51
[16] I. Riethmuller-Haage, L. Bastiaans, C. Kempenaar, V. Smunty and M. J. Kropff, "Are Pre-Spraying Growing Conditions a Major Determinant of Herbicide Efficacy?" Weed Research, Vol. 47, No. 5, 2007, pp. 415-424. doi:10.1111/j.1365-3180.2007.00584.x

[17] D. D. Buhler, "Early Preplant Atrazine and Metolachlor in Conservation Tillage Corn (Zea mays)," Weed Technology, Vol. 5, 1991, pp. 66-71.

[18] D. D. Buhler and V. L. Werling, "Weed Control from Imazaquin and Metolachlor in No-Till Soybeans (Glycine max)," Weed Science, Vol. 37, 1989, pp. 392-399.

[19] K. M. Novosel, K. A Renner, J. J. Kells and E. Spandl, "Metolachlor Efficacy as Influenced by Three Acetolactate Synthase-Inhibiting Herbicides," Weed Technology, Vol. 12, 1998, pp. 248-253.

[20] F.P. Salzman and K. A. Renner, "Response of Soybean to Combinations of Clomazone, Metribuzin, Linuron, Alachlor, and Atrazine," Weed Technology, Vol. 6, 1992, pp. 922-929.

[21] W.A Bailey, H. P. Wilson and T. E. Hines, "Influence of Cultivation and Herbicide Programs on Weed Control and Net Returns in Potato (Solanum tuberosum)," Weed Technology, Vol. 15, No. 4, 2001, pp. 654-659.

doi:10.1614/0890-037X(2001)015[0654:IOCAHP]2.0.C $\underline{\mathrm{O} ; 2}$

[22] J. P. Kelley and T. F. Peeper, "MON 37500 Application Timing Affects Cheat (Bromus secalinus) Control and Winter Wheat," Weed Science, Vol. 51, No. 2, 2003, pp. 231-236. doi:10.1614/0043-1745(2003)051[0231:MATACB]2.0.C $\underline{\mathrm{O} ; 2}$

[23] P. Sikkema, W. Deen and S.Vyas, "Weed Control in Pea with Reduced Rates of Imazethapyr Applied Preemergence and Postemergence," Weed Technology, Vol. 19, No. 1, 2005, pp. 14-18. doi:10.1614/WT-03-051R3

[24] C. M. Boerboom, D. E. Stolenberg, M. R. Jeschke, T. L. Trower and J. M. Gaska, "Factors Affecting Glyphosate Control of Common Lambsquarters," North Central Weed Science Society Proceeding, Vol. 61, 2006, p. 54.

[25] K. N. Reddy and M. A. Locke, "Imazaquin Spray Retention, Foliar Washoff Andrunoff Losses under Simulated Rainfall," Pesticide Science, Vol. 48, No. 2, 1996, pp. 179-187. doi:10.1002/(SICI)1096-9063(199610)48:2<179::AID-PS 457>3.0.CO;2-M

[26] Anonymous, "Frontier ${ }^{\circledR}$ Herbicide Product Label," Mississauga, ON, BASF Canada Inc., 2008, 17 p.

[27] Ontario Ministry of Agriculture, Food and Rural Affairs (OMAFRA), "Guide to Weed Control, Publication 75," Toronto, ON, 2008, 379 p.

[28] L. E. Steckel, C. L. Sprague and A. G. Hager, "Common Waterhemp (Amaranthus rudis) Control in Corn (Zea mays) with Single Preemergence and Sequential Applications of Residual Herbicides," Weed Technology, Vol. 16, No. 4, 2002, pp. 755-761.

doi:10.1614/0890-037X(2002)016[0755:CWARCI]2.0.C $\underline{\mathrm{O} ; 2}$

[29] S. Taylor-Lovell, G. K. Sims, L. M. Wax and J. J. Hassett, 
"Hydrolysis and Soil Adsorption of the Labile Herbicide Isoxaflutole," Environmental Science \& Technology, Vol. 34, No. 15, 2000, pp. 3186-3190. doi:10.1021/es991382f

[30] Y. Lee, H. Kim, J. Chung and B. Jeong, "Loss of Pendimethalin in Runoff and Leaching from Turfgrass Land under Simulated Rainfall," Journal of Agricultural and Food Chemistry, Vol. 48, No. 11, 2000, pp. 5376-5382. doi:10.1021/jf0005869

[31] K. E. Savage, "Persistence of Several Dinitroaniline Herbicides as Affected by Soil Moisture," Weed Science, Vol. 26, 1978, pp. 465-471.

[32] J. Li., W. G. Johnson and R. J. Smeda, "Interactions between Glyphosate and Imazethapyr on Four Annual Weeds," Crop Protection, Vol. 21, No. 10, 2002, pp. 1087-1092. doi:10.1016/S0261-2194(02)00047-9

[33] L. C. Gonzini, S. E. Hart and L. M. Wax, "Herbicide Combinations for Weed Management in Glyphosate-Resistant Soybean (Glycine max)," Weed Technology, Vol. 13, 1999, pp. 354-360.

[34] R. E. Nurse, A. S. Hamill, C. J. Swanton, F. J. Tardif, W. Deen and P. H.Sikkema, "Is the Application of a Residual Herbicide Required Prior to Glyphosate Application in No-Till Glyphosate-Tolerant Soybean (Glycine max)?" Crop Protection, Vol. 26, No. 4, 2007, pp. 484-489. doi:10.1016/i.cropro.2006.04.018

[35] S. A. Payne and L. R. Oliver, "Weed Control Programs in Drilled Glyphosate-Resistant Soybean," Weed Technology, Vol. 14, No. 2, 2000, pp. 413-422. doi:10.1614/0890-037X(2000)014[0413:WCPIDG]2.0.C $\mathrm{O} ; 2$

[36] J. W. Barnes and L. R. Oliver, "Cloransulam Antagonizes
Annual Grass Control with Aryloxyphenoxypropionate Graminicides but Not Cyclohexanediones," Weed Technology, Vol. 18, No. 3, 2004, pp. 763-772. doi:10.1614/WT-03-181R

[37] R. E. Nurse, C. J. Swanton, F. J. Tardif and P. H. Sikkema, "Weed Control and Yield Are Improved When Glyphosate Is Preceded by a Residual Herbicide in Glyphosate-Tolerant Maize (Zea mays)," Crop Protection, Vol. 25, No. 11, 2006, pp. 1174-1179. doi:10.1016/j.cropro.2006.02.015

[38] Statistical Analysis Systems, "The SAS System for Windows," Release 8.0, Statistical Analysis Systems Institute, Cary, 2000, $3884 \mathrm{p}$

[39] Anonymous, "Outlook ${ }^{\circledR}$ Herbicide Product Label," BASF Corporation, Research Park Triangle, 2008, 17 p.

[40] B. G. Young, S. E. Hart and F. W. Simmons, "Preemergence Weed Control in Conventional-Till Corn (Zea mays) with RPA 201772," Weed Technology, Vol. 13, 1999, pp. 471-477.

[41] C. L. Schuster, K. Al-Khatib and J. A. Dille, "Mechanism of Antagonism of Mesotrione on Sulfonylurea Herbicides," Weed Science, Vol. 55, No. 5, 2007, pp. 429434. doi:10.1614/WS-06-217.1

[42] C. L. Schuster, K. Al-Khatib and J. A. Dille, "Efficacy of Sulfonylurea Herbicides When Tank Mixed with Mesotrione," Weed Technology, Vol. 22, No. 2, 2008, pp. 222230. doi:10.1614/WT-07-131.1

[43] C. A. Morton and R. G. Harvey, "Simulated Environments Influence Primisulfuron Efficacy," Weed Science, Vol. 42, 1994, pp. 424-429. 